\title{
「とちぎ夢大地応援団」の運営と地域資源保全ボランティアの参加動機
}

\section{Operations of Organization, and Motives for Participating: A Case Study "Organization of Collaboration for Local Resources in Tochigi.Pre."}

\author{
田中 美香*
}

\section{Mika TANAKA}

\begin{abstract}
The aim of this research is to clarify the actual condition of continuous preservation activities in hilly and mountainous areas. Specifically, it is as follows ; 1)volunteer system with the fund of Tochigi Pre, 2) the contents of activity, 3)volunteer's consciousness. The preparation period of "Organization of Collaboration for Local Resources in Tochigi Pre." is in 2002 - 2004. The organization which established in 2005 is working in 2016. Researching methods are documentation, interview, participant observation, and questionnaire. The candidate for investigation is as follows ; 1) Agricultural Policy Planning Department in Tochigi Prefecture, 2) Tochigi Agriculture Public Corporation, 3) organization in hilly and mountainous areas, 4) volunteers. The result is as follows : 1)administration is managing the volunteer continuously by fund and cooperation, 2)cooperation is towns and cities, an organization of management, and organization of hilly and mountainous areas, 3)registration of a volunteer member enables continued activity. Volunteer's participating motive is as follow;1)the contribution of environmental conservation activities, 2)experience of a beautiful scene and wonderful Satoyama. Activity of hope is as follows; 1) cutting of weeds, 2)maintenance of irrigation canal, 3)afforestation, 4)preservation of ecosystem.
\end{abstract}

Keywords : hilly and mountainous areas, initiative of local administration, fund, cooperation, urban-rural exchange, maintenance

キーワード：中山間地域,行政主導, 基金, 連携, 都市農村交流, 維持管理

\section{1. 背景と目的}

近年，高齢化と少子化に伴う農業者の減少は，農山村の維持管 理を困難化している。こうした背景のもと 1999 年に制定された 「食料・農業・農村基本法」において，農業・農村の多面的機能 とは「国土の保全，水源のかん養，自然環境の保全，良好な景観 の形成, 文化の伝承等農村で農業生産活動が行われることにより 生ずる食料その他の農産物の供給の機能以外の多面にわたる機 能」(同法第三条) とされている。また, 傾斜地となる中山間地域 の多面的機能を保全するための維持管理は，平野部と比較して農 業者の負荷が一般的に高いと考えられる。

農林水産省は「ふるさと水と土保全対策」において，「中山間ふ るさと・水と土保全対策事業 (ふる水基金)」を 1993～1997年度 に実施した。これにより，42 道府県は国から 1/3 の補助を 5 力年 間受け，合計 330 億円の「ふる水基金」が造成された ${ }^{1}$ 。なお， 2014 年度時点での基金の全国残高は 297 億円である ${ }^{2)}$ 。また, 農林水産省は「中山間ふるさと・水と土保全推進事業 (棚田基金)」 を 1998〜2000 年度に実施した。37 道府県は国より 1/3の補助を 3 年間受け，「棚田基金」が造成された。なお， 2014 年度時点で の基金の全国残高は，160 億円となっている2）。

1993 年に栃木県（現）農政部は，「杤木県中山間地域農村環境 保全基金条例」を制定した。これは，農林水産省の「ふる水基金」 と「棚田基金」に対応したものである。「杤木県中山間地域農村環 境保全（水と土・棚田）基金」を利活用して中山間地域農村環境 保全事業は実施されている。その一つである「とちぎ夢大地応援 団」は2005年から開始となり, 2016 年現在も杤木県農政部によっ て運営されている。「とちぎ夢大地応援団」の活動目的は, 1)豊か な農村の維持・保全，2)ボランティアと地域住民が協力し合える パートナーシップの構築，3)豊かな地域資源の創造と継承，であ る。

「ふる水基金」は，農村地域の活性化につながる活動を支援し てきた ${ }^{3)}$ 。具体的には，「とくしま農山漁村応援し隊」での民間企
業・NPO・大学などが県と共同で行う農作業や環境保全のための ボランティアが挙げられる。行政である徳島県の役割は，推進会 議や研修会などの開催・活動や農山漁村の情報をP Rすることに ある 4) 5)。他の事例としては，東京都桜ヶ丘公園の雑木林 $2 \mathrm{ha}$ を 維持管理するボランティアによる順㐫的な植生管理は専門性を要 するため困難であることを，倉本・麻生（2001）は指摘6)してい る。また, 藤木ら (2012) は行政主導のボランティア活動を恒常 的に行うことは困難としているため，「ふるさとボランティア」を 事例として市民主体のボランティア組織への形成プロセスを分析 している7)。

しかしながら，行政主導による継続的な保全活動の有効性につ いて十分な検証がされたとはいいがたい。そこで本研究は，基金 を利活用した地域資源保全活動とボランティアの参加実態・参加 動機をもとに，行政主導によるボランティア活動継続の有效性を 明らかにすることを目的とする。ひを明らかにすることにより， 基金を利活用した継続的な運営によって，中山間地域の多面的機 能の保全が容易になると思われる。なお，本研究のボランティア とは都市部住民が中山間地域にて地域資源の保全活動を行うこと をさす。

\section{2. 研究の方法}

調査期間は, 2013 年 11 月〜 2016 年 6 月とした。調査対象は, 1) 栃木県農政部, 2)公益財団法人栃木県農業振興公社 (以下, 公社), 3）「とちぎ夢大地応援団」の活動，4）「とちぎ夢大地応援団」に 参加する地域資源保全ボランティア，である。調查方法は，杤木 県農政部・公社 からご提供頂いた内部資料と広報誌, 栃木県農政 部と公社が実施した地域資源保全ボランティアを対象としたアン ケート分析 (2012 年 9 月 2016 年 3 月), 参与観察 (2014 年 4 月〜 2016 年 5 月), 聞き取り (2013 年 11 月〜 2016 年 6 月), と した。

*東京農工大学大学院 
調査対象の選定理由は，1）「とちぎ夢大地応援団」が「水と土・ 棚田基金」によって実施，2)栃木県内にて継続的に運営, (3)地域 資源保全ボランティアの登録制度を実施，4)活動内容の簡易性に ある。なお，使用した地図ソフトは，MANDARA Ver.9.45，統 計解析ソフトはSPSS17.0である。

\section{3. 調査対象地の概要}

2016 年時点, 14 市 11 町からなる杤木県の中山間地域は 9 市 5 町である。2010年の国勢調査 ${ }^{8)}$ において, 杤木県の人口は約 200 万人, 平均年齢は 44.8 歳, 総世帯数約 74 万となっている。また, 県庁所在地に位置する宇都宮市の人口は県最大の約 51 万人（栃 木県内の $26 \%$ ), 平均年齢は 43.3 歳, 総世帯数は約 21 万（杤木 県内の 28\%) である。15 歳以上就業者数において，杤木県全体 は第一次産業 $5.8 \%$ ・第二次産業 $32.0 \%$ ・第三次産業 $62.1 \%$ ，宇 都宮市は第一次産業 $2.5 \%$ ・第二次産業 $26.1 \%$ ・第三次産業 $71.4 \%$ となっている。すなわち，杤木県は第一次産業就業者が県全体に 点在し, 最大人口が在住する宇都宮市は第二次・第三次産業の就 業者が多数在住している。

\section{4. 結果と考察}

\section{（1）「とちぎ夢大地応援団」設立の経緯}

「とちぎ夢大地応援団」は，2002 年 10 月～2004年 10 月まで の栃木県の中山間地域にて実施された活動をへて 2005 年 1 月に 設立された。杤木県農政部による実施された活動とは，県内の都 市部住民を対象とした 1)農山村の視察，2)そば打ち体験，3)公募 によるボランティアの棚田での稲刈り・畦畔保全としての草刈 り・ホタル生息地での用水路の清掃，である。

\section{（2）「とちぎ夢大地応援団」システムの実態}

図-1 に地域資源保全ボランティアの募集と登録概要を示した。 地域資源保全ボランティアとして登録されると，登録した住所 に 1)年 2 回発行される広報誌（年間案内と活動報告） ${ }^{9}$ ， 2)活動 地の地図が添付された活動の案内と参加申込用紙（申込先は公 社）10）が郵送される。なお，学生は団体会員として登録されてい
るため, 学生の所属する学校に広報誌と活動の案内が郵送される。

図一211)に「とちぎ夢大地応援団」運営の流れを示した。「とち ぎ夢大地応援団」の活動地と活動地が希望する活動内容の情報は, 杤木県農政部の各振興事務所と連携先の杤木県内市町から杤木県 農政部へと提供される 12 。

運営に関する具体的な流れは，以下のとおりである。杤木県農 政部と農山村地区の活動組織が活動の合意形成を成立後，栃木県 農政部・活動地の市町行政・公社・活動組織は現地の調査を行い,

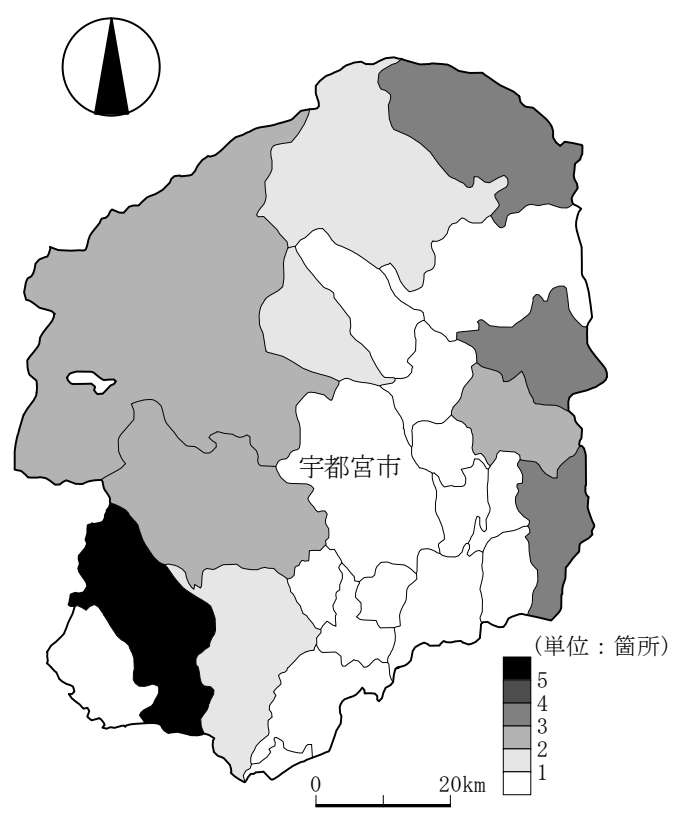

図一个「とちぎ夢大地応援団」の一市町当たりの活動地数

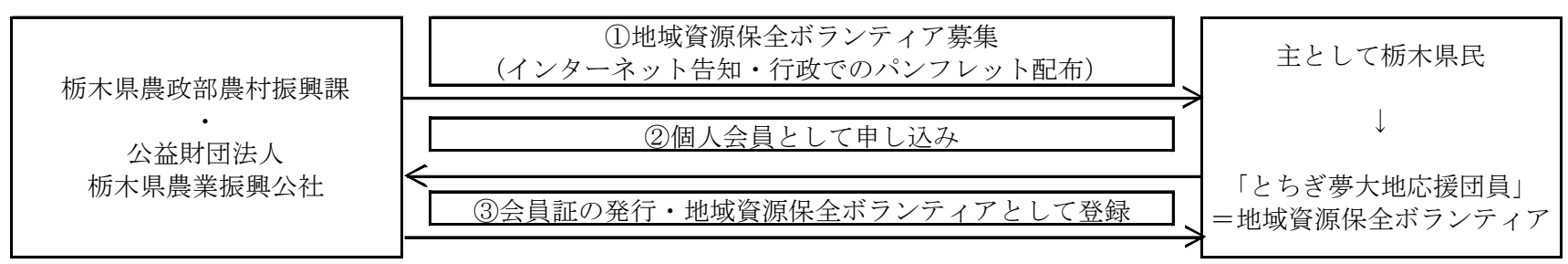

図-1＼cjkstart地域資源保全ボランティアの募集・登録

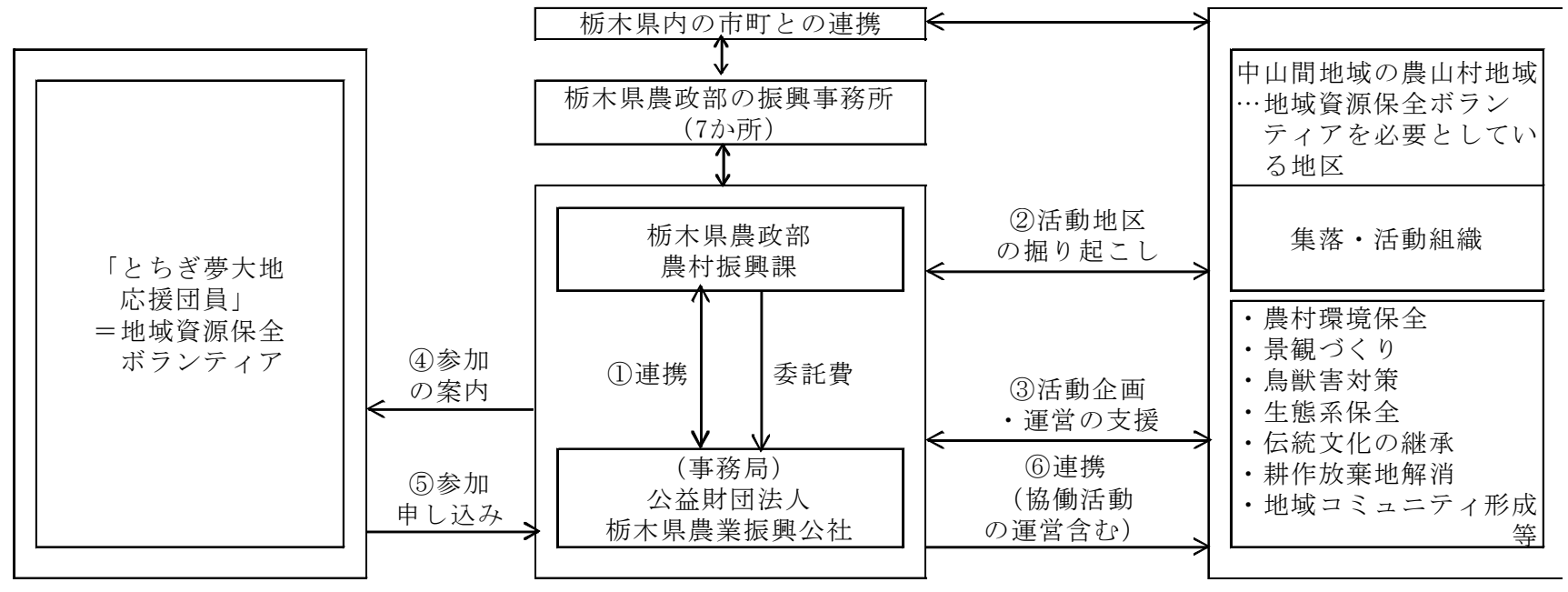

図一2 地域資源保全ボランティア運営の全体図 


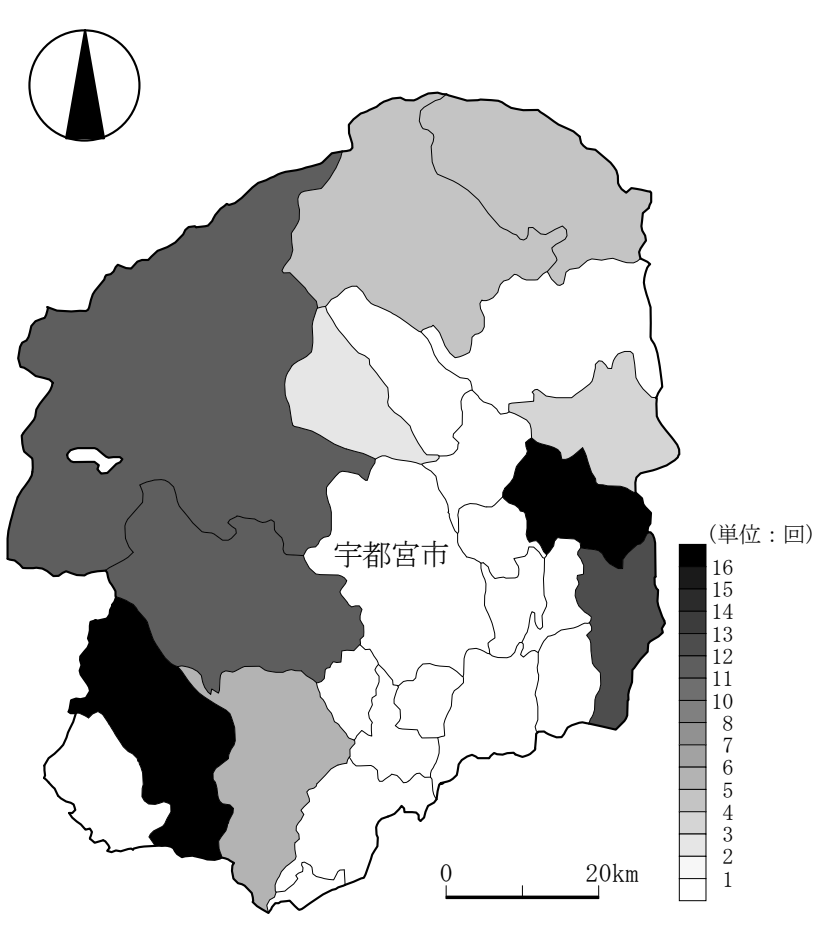

図ー4「とちき夢大地応援団」の一市町当たりの累計活動回数

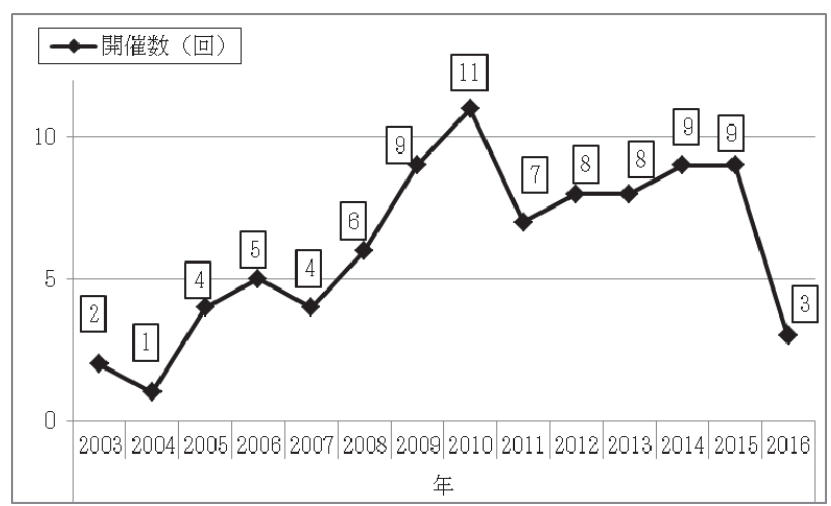

図一5「とちぎ夢大地応援団」での一年間の活動回数 ${ }^{14)}$

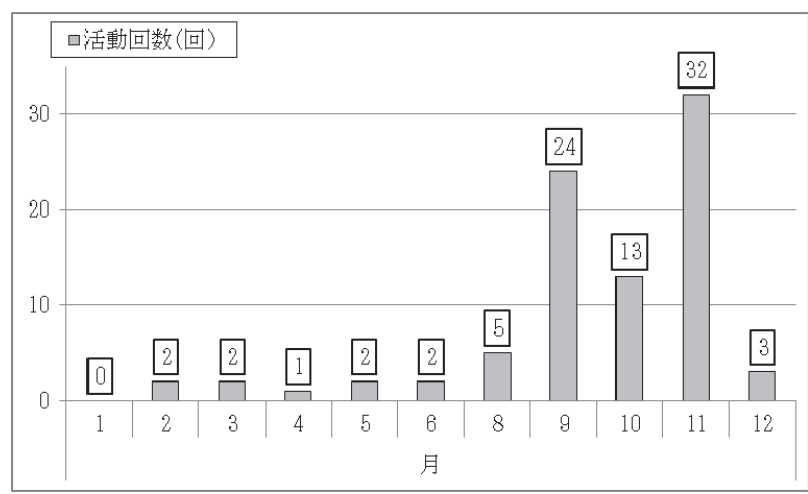

図－6「とちぎ夢大地応援団」の月別活動回数

活動の日程・活動内容の役割分担と連携を決定する。それに基づ いて, 公社と活動組織は随時実施内容の打会わせを行う。また, 実施予定日の 30〜60 日前に，公社は地域資源保全ボランティア 一参加募集の案内を郵送・公社Web での告知を実施する。「とち ぎ夢大地応援団」の活動日当日は, 公社から 1 名, 杤木県農政部

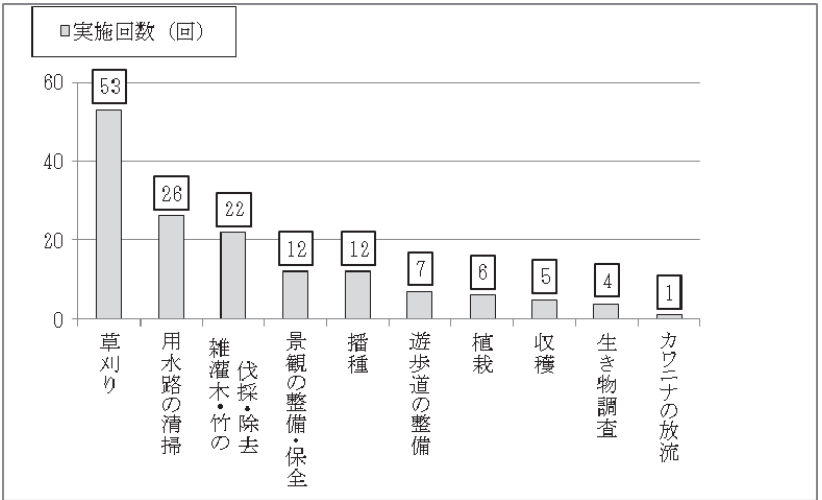

図-7「とちき夢大地応援団」の活動内容別回数

農村振興課から 1 名, 活動地を担当とする各振興事務所から $3 \sim 5$ 名, 活動地の市町行政から 1〜2 名の参加が通例となっており, 地域資源保全ボランティアとほぼ同様の活動を担っている。なお, 杤木県職員のボランティア活動が通常となっている要因とし て，1)栃木県の農業普及員は他県よりも多数 ${ }^{13)}$ ，2）「とちぎ夢大 地応援団」設立前の活動として公募に応募した県職員が中山間地 域で草刈りをボランティア活動したことが挙げられる。

図一 3 は, 栃木県全体の活動地 6 市 4 町の 24 地区と一市町当 たりの活動地を示した。県南以外の県境ほぼすべての市町が活動 地である。

図一 4 は, 6 市 4 町での一市町当たりの累計活動回数を示した。 一市町の活動回数は, 最小 2 回・最大 17 回・平均 8.5 回となっ た。

図一 5 は, 2003 年 9 月〜 2016 年 5 月までのボランティア活動 状況を示した。「とちぎ夢大地応援団」は 14 年間で累計 86 回開 催され, 年平均 6.1 回となっている。なお, 2016 年は 5 月までの 活動実績となっており, 2015 年と同程度の活動が予定されている。

図一 6 は, 2003 年 9 月〜2016 年 5 月までの月別の活動回数を 示した。最多は 11 月の 32 回 (37\%), 次いで9月の 24 回 (28\%) である。また，9１1月の活動は全体の 80\%を占めている。これ は，農閑期となる稲刈り後に活動が実施されるためである。

図一7は, 2003 年 9 月〜2016 年5月までの活動内容を示した。 最多は草刚りの 53 件 (36\%) となった。また, 草刚りに伴って 杂嚾木・竹の伐採・除去 $(22$ 件・15\%) が必要となる場合もある。 すなわち, 草刚りと雑灌木 - 竹の伐採・除去による遊休農地の保 全が全体の $51 \%$ を占めている。なお, 1 回の活動において, 複数 の作業を行うことは, 通常認められる。具体的には, 86 回の活動 のうち, 148 件の作業内容 ( 1 活動あたり 1.7 種類の作業) となっ ている。

（3）地域資源保全ボランティアの実態

1）登録済み地域資源保全ボランティアの概要

図一8 は，地域資源保全ボランティアの加入状況を示した。特 徵として，「とちぎ夢大地応援団」設立後である 2005〜2007 年で の毎年約 70〜180 名の会員登録が挙げられる。また, その後は年 間 4 30 名程度の会員登録となっており, 累計会員数は 440名と なっている 15)。なお, 「とちぎ夢大地応援団」の活動参加は, 会 員登録が必須の条件となっていない。そのため, 活動の情報を得 た会員が公社に参加申込する際に友人・家族を記入し, 共に活動 することは通常認められる。

図-9は，「とちぎ夢大地応援団」に登録している地域資源保全 ボランティアの住所を示した。地域資源保全ボランティアの $47 \%$

(228 名中 108 名) は, 県庁所在地の中核市である宇都宮市に在 住している。なお, 学生会員約 200 名の住所は不明となっている ものの，学校の所在地はいずれも宇都宮市内である。 


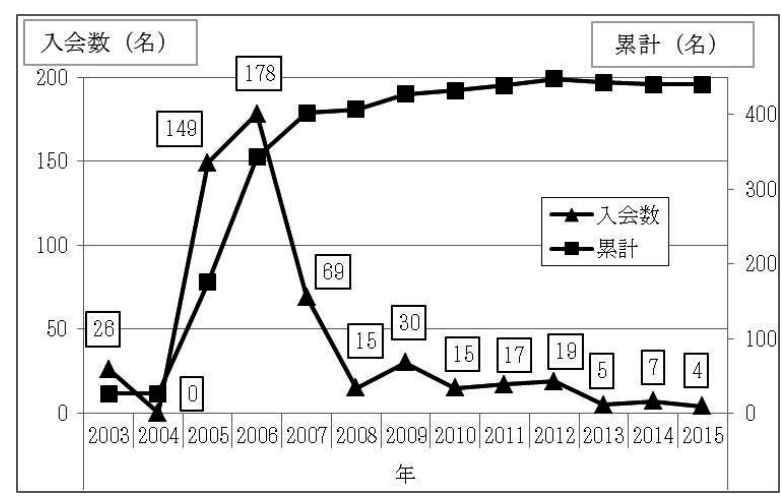

図-8 地域資源保全ボランティアの入会数と累計人数

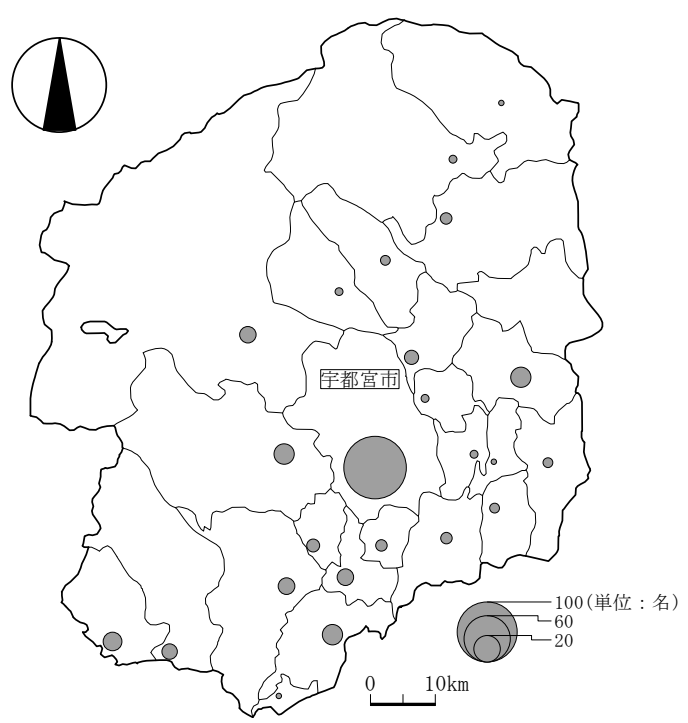

図-9 地域資源保全ボランティアの在住地 $(n=228)$

注）栃木県以外の地域資源保全ボランティアの登録済み住所は,

茨城県 と宮城県が各 1 名・埼玉県と 東京都が各 2 名。

表一1 地域資源保全ボランティアの属性（ $n=440 ） （$ 単位 : 名）

\begin{tabular}{|c|c|c|c|c|c|}
\hline \multirow{2}{*}{ 世代 } & \multicolumn{3}{|c|}{ 性別 } & \multirow[b]{2}{*}{ 計 } & \multirow{2}{*}{ 構成比 } \\
\hline & 男 & 女 & 不明 & & \\
\hline 10歳以下 & 1 & 4 & & 5 & $1 \%$ \\
\hline 10 代 & 2 & & & 2 & $0 \%$ \\
\hline 20 代 & 7 & 1 & & 8 & $2 \%$ \\
\hline 30 代 & 18 & 9 & & 27 & $6 \%$ \\
\hline 40代 & 33 & 8 & & 41 & $9 \%$ \\
\hline 50 代 & 36 & 17 & & 53 & $12 \%$ \\
\hline 60 代 & 49 & 19 & & 68 & $15 \%$ \\
\hline 70 代 & 12 & 2 & & 14 & $3 \%$ \\
\hline 学生* & 93 & 93 & 20 & 206 & $47 \%$ \\
\hline 不明 & 12 & 3 & 1 & 16 & $4 \%$ \\
\hline 計 & 263 & 156 & 21 & 440 & $100 \%$ \\
\hline 構成比 & $60 \%$ & $35 \%$ & $5 \%$ & $100 \%$ & --- \\
\hline
\end{tabular}

注）*は，高校生〜大学生か該当。

表一 1 は, 登録済夕地域資源保全ボランティアの属性を示した。 特徵として，1)高校生～大学生の $47 \% ， 2) 50$ 代〜 70 代の $30 \%$ が 挙げられる。なお，表一 1 と表一 2 の属性は，地域資源保全ボラ ンティア登録時の情報であり現時点と異なっているため, 留意が
表一2 地域資源保全ボランティアの職業 ${ }^{16)} \quad(n=440)$ (単位 : 名)

\begin{tabular}{r|l|r|r}
\hline No. & \multicolumn{1}{|c|}{ 職業名 } & 会員数 & 構成比 \\
\hline 1 | 学生 & 214 & $49 \%$ \\
\hline 2 公務員 & 49 & $11 \%$ \\
\hline 3 会社員 & 23 & $5 \%$ \\
\hline 4 無職 & 15 & $3 \%$ \\
\hline 5 主婦 & 12 & $3 \%$ \\
\hline 6 農業者 & 11 & $3 \%$ \\
\hline 7 アルバイト・パート & 8 & $2 \%$ \\
\hline .フリーター & 22 & $5 \%$ \\
\hline 8 & その他 & 86 & $20 \%$ \\
\hline 9 不明 & 440 & $100 \%$ \\
\hline
\end{tabular}

必要である。

表一2 は, 登録済み地域資源保全ボランティアの職業を示した。 特徴として，1)学生の $49 \%$ ，2)公務員の $11 \%$ が挙げられる。公務 員の登録は，「とちぎ夢大地応援団」の設立前に, 栃木県職員がボ ランティアによる草刚り活動したことに起因するものと推測され る。

2）活動者である地域資源保全ボランティアの特徵

図-10 は, 栃木県農政部と公社が実施した地域資源保全ボラン ティアを対象とした 2012 年 9 月〜2016 年 3 月まで 36 回分のア ンケート状況を示した ${ }^{17)}$ 。1 活動当たり約 $11 \sim 20$ 件, 年間約 90 〜150 件となっている。

表-3 は, 活動している地域資源保全ボランティアの参加実態 として属性を示した。性別では男性が優位に多数 $\left(x^{2}=147.925\right.$, $\mathrm{df}=1, \mathrm{p}<0.001$ ）となった。世代は，20 代と 60～70 代が全体の $62 \%$ 占めている。

図-11 は, 2012 年 9 月〜2016 年 3 月までのアンケート期間で の「とちぎ夢大地応援団」の活動内容を示した。参加実態として 最多の活動内容は中山間地域の景観保全に必須となる遊休農地の 草刈り, 杂嚾木·竹の伐採・除去が 59 件中 37 件・ $63 \%$ を占めた。

表一 4 は，地域資源保全ボランティアが「とちぎ夢大地応援団」 の活動に参加するきっかけを示した。地域資源保全ボランティア の登録住所に郵送される「活動の申込案内」と「広報誌」は有力 なきっかけとなっている。また, 公社の運営する「とちぎ夢大地 応援団」のWeb も有効だと認められる ${ }^{18)}$ 。なお, 「之の他」は聞 き取り調査とアンケート回答より登録済みの地域資源保全ボラン ティアからの紹介と推測される。

表一 5 は，地域資源保全ボランティアが希望する活動の矅日と 時間を示した。最大は休日である土曜日と日曜日 (72\%), 時間 帯は午前のみ $(86 \%)$ となった。

表一 6 は，地域資源保全ボランティアの参加動機となる中山間

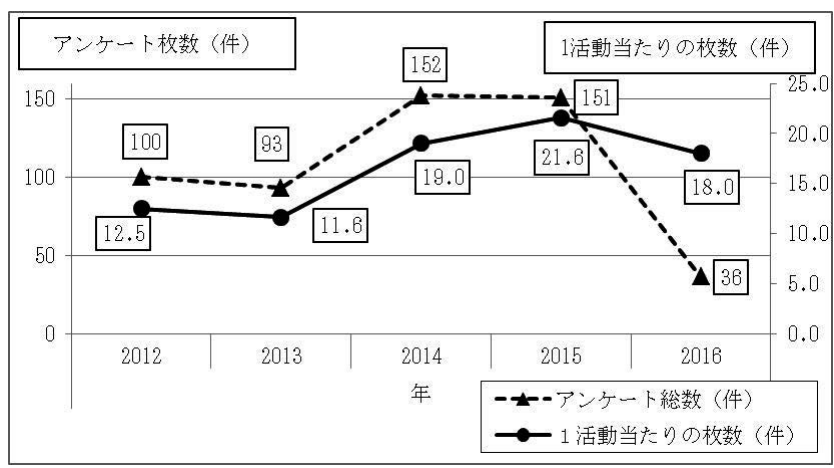

図一10 地域資源保全ボランティアのアンケート状況（n=532） 
表-3 アンケート回答者の属性（ $n=532 ） （$ 単位 : 名）

\begin{tabular}{|c|c|c|c|c|c|}
\hline \multirow{2}{*}{ 世代 } & \multicolumn{3}{|c|}{ 性別 } & \multirow{2}{*}{ 計 } & \multirow{2}{*}{ 構成比 } \\
\hline & 男 & 女 & 未記入 & & \\
\hline 10歳以下 & 2 & & $1]$ & 3 & $1 \%$ \\
\hline 10代 & 21 & 19 & 1 & 41 & $8 \%$ \\
\hline 20代 & 56 & 42 & & 98 & $18 \%$ \\
\hline 30 代 & 31 & 11 & & 42 & $8 \%$ \\
\hline 40 代 & 50 & 14 & & 64 & $12 \%$ \\
\hline 50代 & 46 & & & 46 & $9 \%$ \\
\hline 60 代 & 126 & 19 & & 145 & $27 \%$ \\
\hline 70 代 & 66 & 20 & & 86 & $16 \%$ \\
\hline 80代 & 7 & & & 7 & $1 \%$ \\
\hline 計 & 405 & 125 & 2 & 532 & $100 \%$ \\
\hline 構成比 & $76 \%$ & $23 \%$ & $0 \%$ & $100 \%$ & --- \\
\hline
\end{tabular}

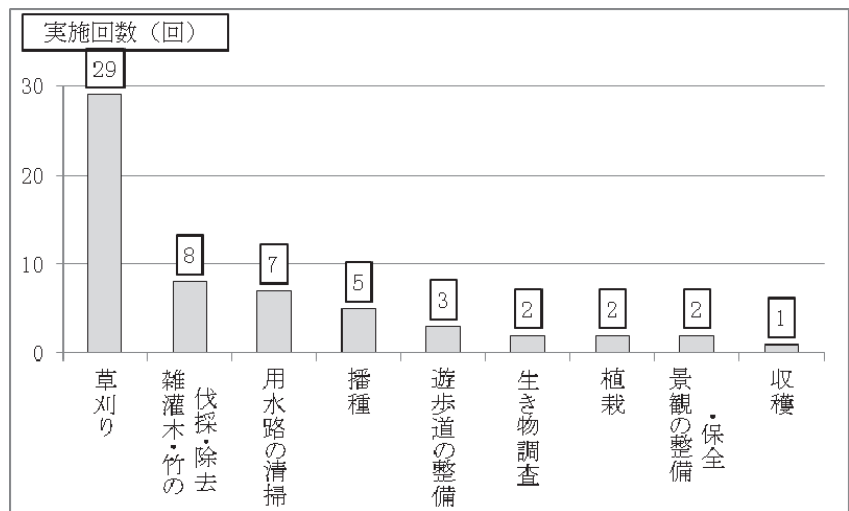

図-11「とちぎ夢大地応援団」の活動内容（単位 : 回）

表一4 活動参加のきっかけ（ $\mathrm{n}=532$, 複数回答）（単位 : 件）

\begin{tabular}{|c|c|c|c|c|c|c|c|}
\hline 年代 & $\begin{array}{c}\text { 活動 } \\
\text { の申込 } \\
\text { 案内 }\end{array}$ & $\begin{array}{c}\text { 「ちちぎ } \\
\text { 夢大地 } \\
\text { 応援団」 } \\
\text { のWeb }\end{array}$ & $\begin{array}{c}\text { 「ちちぎ } \\
\text { 夢大地 } \\
\text { 応援団」 } \\
\text { の広報誌 }\end{array}$ & ラジオ & 新聞 & その他 & 構成比 \\
\hline $\begin{array}{l}\text { 10歳 } \\
\text { 以下 }\end{array}$ & 1 & & & & & 2 & $1 \%$ \\
\hline 10 代 & & $1]$ & 2 & & & 39 & $8 \%$ \\
\hline 20代 & 25 & 31 & 4 & & & 48 & $20 \%$ \\
\hline 30代 & 15 & 14 & 3 & & & 18 & $9 \%$ \\
\hline 40代 & 29 & 29 & 4 & & 1 & 21 & $16 \%$ \\
\hline 50代 & 15 & 14 & 5 & & & 19 & $10 \%$ \\
\hline 60代 & 71 & 35 & 31 & & & 37 & $33 \%$ \\
\hline 70代 & 43 & 18 & 8 & 1 & 1 & 22 & $17 \%$ \\
\hline 80 代 & & & & & 1 & 6 & $1 \%$ \\
\hline 構成比 & $37 \%$ & $27 \%$ & $11 \%$ & $0 \%$ & $1 \%$ & $40 \%$ & --- \\
\hline
\end{tabular}

表一5 活動の希望曜日 - 時間帯（ $n=532$, 単数回答）（単位 : 件）

\begin{tabular}{|c|c|c|c|c|c|c|}
\hline \multirow[b]{2}{*}{ 曜日 } & \multicolumn{4}{|c|}{$\begin{array}{l}\text { 時間帯 } \\
\end{array}$} & \multirow[b]{2}{*}{ 計 } & \multirow[b]{2}{*}{ 構成比 } \\
\hline & 午前のみ & $\begin{array}{c}\text { 午前 } \\
\text { と午後 }\end{array}$ & 午後のみ & その他 & & \\
\hline $\begin{array}{c}\text { 土曜日 } \\
\text { ・日曜日 }\end{array}$ & 338 & 39 & 4 & 2 & 383 & $72 \%$ \\
\hline 希望なし & 80 & 24 & & 2 & 106 & $20 \%$ \\
\hline 平日 & 39 & 2 & 1 & & 42 & $8 \%$ \\
\hline その他 & 1 & & & & 1 & $0 \%$ \\
\hline 計 & 458 & 65 & 5 & 4 & 532 & $100 \%$ \\
\hline 構成比 & $86 \%$ & $12 \%$ & $1 \%$ & $1 \%$ & $100 \%$ & -- \\
\hline
\end{tabular}

地域の魅力を示した。ほぼ全世代が第一位として「美しい景観」 を挙げた。また，「美しい景観」・「きれいな空気や水」「穴のやす
らぎ」は, 全世代の主要な要因となった。

表一7は，地域資源保全ボランティアが「とちぎ夢大地応援団」 の活動に参加する動機を示した。10 代での最大数となった参加動 機は「美しい景観・すばらしい自然を体験」である。一方，20〜 80 代の最大数の参加動機は「環境保全活動の貢献」を示した。

表一8 は，地域資源保全ボランティアが今後希望する活動内容 を示した。10歳以下と 20 代を除く世代は，現在の主たる作業と なっている「用水路清掃・遊休農地の草刚り」を第一希望とした。 なお， 20 代のみが「植栽・生態系保全活動」19）を第一希望の作 業として挙げた。くわえて, 現在主たる作業となっていない「農 業のお手伝い」も，40～60 代と 80 代に希望者が認められた。こ れは，遊休農地の有効活用を志向していると推測される。

表一 $6 \cdot 7$ における中山間地域の「美しい景観」とは, 維持管理 されている立体的・曲線的な空間である里山と, 農業者によって 作付されている直線的に整備された田畑から形成される複合的な 要素をもつ土と植物による景観である。「美しい景観」は，表一7 に示した人による「環境保全活動」である維持管理を必須とする。 また，「美しい景観」を維持することにより多面的機能と地域資源 は保全される。表一6にある中山間地域の魅力である「美しい景 観」を保全し，「きれいな空気と水」による「心のや寸らぎ」のた めに，地域資源保全ボランティアは表一7 に示した「環境保全活 動の貢献」を参加動機としている。くわえて, 表一8にある「希 望する作業として，中山間地域の地域資源と多面的機能に必須と なる「用水路清掃・遊休農地の草刚り」を選択していると理解で きる。

\begin{tabular}{|c|c|c|c|c|c|c|c|}
\hline 表一6 & 山䦎 & (U) & $(\mathrm{n}=\mathrm{s}$ & & 今) & & \\
\hline 世代 & $\begin{array}{l}\text { 美 } \\
\text { ᄂ } \\
\text { 心 } \\
\text { 景 } \\
\text { 観 }\end{array}$ & $\begin{array}{l}\text { き } \\
\text { れ空 } \\
\text { い気 } \\
\text { なや } \\
\text { 水 }\end{array}$ & $\begin{array}{l}\text { 心 } \\
\text { の } \\
\text { や } \\
\text { す } \\
ら \\
\text { ぎ }\end{array}$ & $\begin{array}{l}\text { 貴 } \\
\text { 重 } \\
\text { な } \\
\text { 生 } \\
\text { 物 }\end{array}$ & $\begin{array}{l}\text { 伝 } \\
\text { 統. } \\
\text { 文掠 } \\
\text { 化祭 } \\
y\end{array}$ & $\begin{array}{l}\text { そ } \\
\text { の } \\
\text { 他 }\end{array}$ & $\begin{array}{l}\text { 構 } \\
\text { 成 } \\
\text { 比 }\end{array}$ \\
\hline 0歳以下 & 1 & 1 & 1 & & 1 & & $1 \%$ \\
\hline 10代 & 31 & 31 & 30 & 21 & 13 & & $24 \%$ \\
\hline 20 代 & 75 & 67 & 56 & 31 & 32 & 1 & $49 \%$ \\
\hline 30代 & 34 & 31 & 26 & 16 & 14 & & $23 \%$ \\
\hline 40代 & 52 & 50 & 48 & 22 & 7 & & $34 \%$ \\
\hline 50代 & 35 & 31 & 27 & 14 & 12 & 1 & $23 \%$ \\
\hline 60 代 & 105 & 106 & 96 & 53 & 35 & 1 & $74 \%$ \\
\hline 70代 & 75 & 68 & 68 & 33 & 21 & 3 & $50 \%$ \\
\hline 80代 & 6 & 6 & 4 & & 2 & & $3 \%$ \\
\hline 構成比 & $77.8 \%$ & $73.5 \%$ & $66.9 \%$ & $35.7 \%$ & $25.8 \%$ & $1.1 \%$ & --- \\
\hline
\end{tabular}

\section{表 -7 活動の参加動機（ $n=532 ，$ 複数回答）（単位 : 件）}

\begin{tabular}{|c|c|c|c|c|c|c|}
\hline 世代 & $\begin{array}{l}\text { 環 } \\
\text { 境の } \\
\text { 保貢 } \\
\text { 全献 } \\
\text { 活 } \\
\text { 動 }\end{array}$ & 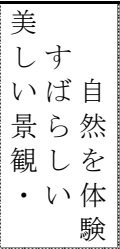 & $\begin{array}{l}\text { 同 } \\
\text { じ人 } \\
\text { 志と } \\
\text { をの } \\
\text { 持交 } \\
\text { つ流 }\end{array}$ & $\begin{array}{l}\text { 健 } \\
\text { 康 } \\
\text { づ一 } \\
<\text { 環 } \\
り\end{array}$ & $\begin{array}{l}\text { そ } \\
\text { の } \\
\text { 他 }\end{array}$ & $\begin{array}{l}\text { 構 } \\
\text { 成 } \\
\text { 比 }\end{array}$ \\
\hline 10歳以下 & 1 & 1 & & 2 & & $1 \%$ \\
\hline 10 代 & 17 & 22 & 7 & 9 & 6 & $11 \%$ \\
\hline 20 代 & 57 & 47 & 24 & 16 & 9 & $29 \%$ \\
\hline 30 代 & 27 & 20 & 5 & 7 & 2 & $11 \%$ \\
\hline 40 代 & 51 & 40 & 24 & 19 & 1 & $25 \%$ \\
\hline 50 代 & 37 & 19 & 20 & 16 & 1 & $17 \%$ \\
\hline 60 代 & 106 & 77 & 67 & 63 & 1 & $59 \%$ \\
\hline 70 代 & 61 & 57 & 52 & 46 & & $41 \%$ \\
\hline 80 代 & 5 & 2 & 2 & 4 & & $2 \%$ \\
\hline 構成比 & $68.0 \%$ & $53.6 \%$ & $37.8 \%$ & $34.2 \%$ & $3.8 \%$ & --- \\
\hline
\end{tabular}




\section{表一8 今後希望する作業（ $\mathrm{n}=532 ，$ 複数回答）（単位 : 件）}

\begin{tabular}{|c|c|c|c|c|c|c|c|}
\hline 世代 & 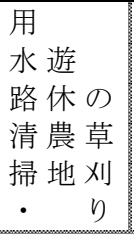 & $\begin{array}{l}\text { 植 } \\
\text { 栽 保 } \\
\text { • 全 } \\
\text { 生 活 } \\
\text { 態 動 } \\
\text { 系 }\end{array}$ & 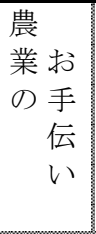 & $\begin{array}{l}\text { 地 } \\
\text { 域文 } \\
\text { の化 } \\
\text { 伝継 } \\
\text { 統承 }\end{array}$ & $\begin{array}{l}\text { そ } \\
\text { の } \\
\text { 他 }\end{array}$ & $\begin{array}{l}\text { 末 } \\
\text { 記 } \\
\text { 入 }\end{array}$ & $\begin{array}{l}\text { 構 } \\
\text { 成 } \\
\text { 比 }\end{array}$ \\
\hline 10歳以下 & 1 & 2 & 1 & & & & $1 \%$ \\
\hline 10 代 & 27 & 19 & 19 & 19 & 2 & & $16 \%$ \\
\hline 20 代 & 49 & 62 & 35 & 48 & 2 & 2 & $37 \%$ \\
\hline 30 代 & 34 & 23 & 14 & 14 & & & $16 \%$ \\
\hline 40代 & 56 & 39 & 30 & 26 & & & $28 \%$ \\
\hline 50 代 & 33 & 22 & 10 & 8 & & 4 & $14 \%$ \\
\hline 60 代 & 100 & 74 & 51 & 35 & 1 & 6 & $50 \%$ \\
\hline 70 代 & 55 & 42 & 11 & 18 & & 10 & $26 \%$ \\
\hline 80 代 & 6 & 1 & 3 & & & & $2 \%$ \\
\hline 構成比 & $68 \%$ & $53 \%$ & $33 \%$ & $32 \%$ & $1 \%$ & $4 \%$ & --- \\
\hline
\end{tabular}

\section{5. まとめ}

本研究は栃木県を事例として，基金を利活用した地域資源保全 活動とボランティアの参加実態・参加動機をもとに，行政主導に よるボランティア活動継続の有効性を明らかにすることを目的と した。その結果，本研究の事例における地域資源保全活動の継続 性は，行政による地域の連携と地域資源保全ボランティアの参加 動機が合致することにより，担保されることが明らかとなった。

行政主導による継続的なボランティア運営は,「ふる水基金」と 「棚田基金」を原資 20) とする連携による運営が必須となる。連 携の対象は, 県内の市町行政・運営委託先の組織・中山間地域の 活動組織である。連携することにより，ボランティアを必要とし ている中山間地域の活動組織と活動内容が明らかとなるため，ボ ランティア運営は可能となる。また，基金を原資とすることによ り行政は円滑なボランティア運営の委託化が容易となるため, シ ステム運営が可能となる。くわえて，中山間地域の農山村でボラ ンティアとして活動を希望する人々を地域資源保全ボランティア として行政が登録管理することにより，地域資源保全活動は可能 となる。なお, 登録済みの地域資源保全ボランティアがその家族・ 知人にボランティアへの参加を勧めることや，行政職員のボラン ティア参加は，システムに有効であることが示唆された。

地域資源保全ボランティアは，1環境保全活動の貢献，2)美し い景観・すばらしい自然を体験すること，を主たる参加動機とし ている。そのためのボランティア活動として，1)用水路清掃・遊 休農地の草刚り，2)植栽・生態系保全活動を希望している。

今後の課題は，活動地となっている遊休農地の活用法を明らか にすることにある。

謝辞 : 調查に協力頂いた栃木県農政部農村振興課中山間地域担当の皆様, 栃木県農業振興公社の南斉様・中里様に感謝の意を表します。本論 文の查読者・論文集委員会からの有益なコメントに深謝致します。

\section{補注及び引用文献}

1）濱口大志（1996）：ふるさと水と土保全対策：農業士木学会誌 64(8), 765-768

2) 農林水産省 http://www.maff.go.jp/j/nousin/tiiki/furumizu.html (2016 年 8 月 24 日閲覽

3）全国土地改良事業団体連合会（2011）：ふるさと水と土基金活動事例 紹介 : 季刊新・田舎人 $69(-), 11-12$

4）全国土地改良事業団体連合会（2015）：ふるさと水と土基金活動事例
紹介 : 季刊新・田舎人 $83(-), 12-13$

5）徳島県農林水産部農山漁村振興課

$h t t p: / / w w w . p r e f . t o k u s h i m a . j p / t a n a d a / o u e n /(2016$ 年 12 月 1 日閲覧)

6) 倉本宣・麻生嘉 (2001) : 里山ボランティアによる雑木林管理-桜ケ丘 公園を例に，135-149:武内和彦・熟谷いら゙み・恒川篤志 (編) : 里山の 環境学: 東京大学出版会, $257 \mathrm{pp}$

7）藤木庄五郎・星野敏・中村省吾・橋本禅・九鬼康彰 (2012)：都市住 民による中山間地域一の継続的支援組織の形成プロセス - 京都府

「ふるさとボランティア」を事例として - , 農村計画学会誌（論文特 集号) $31,285-290$

8）政府統計の総合空口都道府県・市区町村別統計表（国勢調查） http://www.e-stat.go.jp/SG1/estat/GL08020103.do?_toGL08020103_ $\&$ tclass $\mathrm{ID}=000001037709 \&$ cycleCode $=0 \&$ requestSender $=$ search (2016 年 8 月 1 日閲覽

9）「とちぎ夢大地応援団」の広報誌である「はばたけ夢大地」は， http://www.tochigi-agri.or.jp/yumedaichiouendan/yumedaichi/ index.html（2016年 8 月 22 日閲覧）にて公開されている。

10）一部，活動組織の事務局に申し込む場合が認められる。

11）図一2 に示したように，栃木県農政部農村振興課は公社・栃木県農政 部の各振興事務所・栃木県内の市町・中山間地域での農山村地域の活 動組織や集落と連携しつつ「とちぎ夢大地応援団」を運営する。また， 栃木県農政部農村振興課は公社に運営を委託している。なお，「栃木県 中山間地域農村環境保全（水と土・棚田）基金」の収入は基金の利息 のみである。また，「栃木県中山間地域農村環境保全（水と土・棚田） 基金」は，「とちぎ夢大地応援団」以外にも利活用されている。

12)杤木県農政部は新規の活動地として 1 年間に $2 \sim 3$ か所を目標として, 栃木県内にて情報收集を行っている。なお，一地区の活動は， 1 年に 1 回が基本となっている。

13）杤木県農政部にて筆者の聞き取りによる。

14）2011年度は台風の影響により，「とちぎ夢大地応援団」の活動が中止 となった活動地が 5 地区あった。具体的には，那須塩原市高林地区と 関谷地区，鹿沼市中粕尾地区，茂木町河又地区・小貫地区。また，東 日本大震災による岩石崩壊のため, 那須町芦野地区の活動も中止と なった。

15） 2016 年 5 月時点での「とちぎ夢大地応援団」退会者は転居先不明を 含めて累計 94 名である。

16）その他とは以下の通り。会社経営, NPO 関係者, 教育関係者, 団体 職員，医療関係者，飲食業関係，コンサルタント，家事見習い，翻訳 業，理容師。なお，参与観察と聞き取り調査より，NPO 法人「ナル ク」（NALC＝ニッポン・アクティブライフ・クラブ）が組織として 継続的に参加。

17） 36 回分のアンケートデータに, 同一人物が重複回答寸ることによるデ ータ精度の問題点（アンケートに複数回の記入をしたリピーター的な 人物の回答結果が強く反映されること）は，36 回分の「とちぎ夢大地 応援讨」参加者の集合写真とボランティア保険の加入情報より，同一 人物の参加は非常に低いと推則された。そのためデータの精度の影響 は，ほぼ無いと思われる。

18）Webには紙媒体の「とちぎ夢大地応援団」の募集が情報公開されてい るためと推測される。

19）アンケートの設問は「花の植栽等による農山村の景観向上やホタルの 保護等の生態系保全活動」となっている。ここより，植栽と生態系保 全活動は，農山村の環境保全・景観向上に関連すると思われる。

20）農林水産省 2において，「ふる水基金」は地域住民活動を推進する人材 の育成・施設や農地の利活用及び保全整備等の促進に対寸る支援を実 施することを趣旨としている。また，「棚田基金」の趣旨は，都市住民 等の保全活動への参加や住民組織が行う保全活動等の促進に対寸る支 援の実施にある。これら趣旨を統合させた栃木県の「水と土・棚田基 金」によって，「とちぎ夢大地応援団」の運営は可能となっている。 